\title{
Good News for European Vultures
}

SINCE THE OUTBREAK OF BOVINE SPONGIFORM ENCEPHALOPATHY (BSE) IN 2001, THE CONSERvation of European scavengers has been the subject of a legal dilemma: Either we can strictly protect scavenger species (1) or we can destroy livestock carcasses, the scavengers' main source of food (2-5). In 2009, Donázar et al. (3) remarked that it was time for new regula-

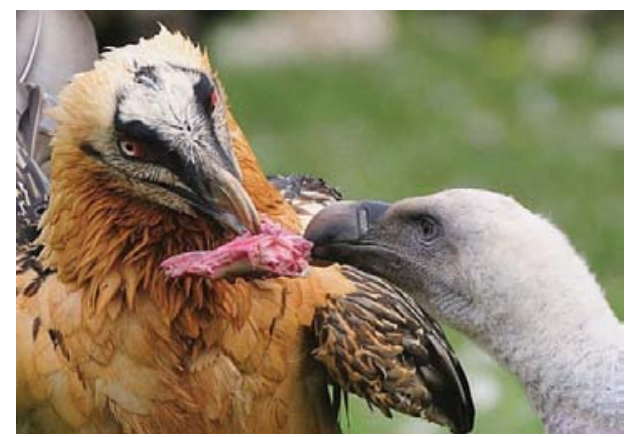
tions and that "encouraging fallen stock to be left in situ is the most ecologically harmonious, inexpensive, and eff icient management method for the conservation of scavengers." Fortunately, recommendations became reality. A broad consensus among scientists, conservationists, and managers (5) led to new EU regulations approved in March 2011 (6, 7). Now, the Spanish government has approved a disposition allowing farmers to abandon the remains of their animals in the field and/or feeding stations (8). Although the application will be subject to some sanitary and administrative restrictions, the new scenario is grounds for optimism about the future of the Spanish vulture populations (which represent about $95 \%$ of European vultures).

With the application of this new measure, Spanish vultures will continue to provide valuable ecosystem services. In Spain alone, avian scavengers are capable of removing 9.9 million tons of carcasses per year. This in turn saves costs for farmers (about $€ 20$ per animal). The industrial destruction of carcasses carries costs between $€ 66$ and $€ 96$ per ton, in addition to the emission of greenhouse gases derived from transport and incineration (5). Overall, these events demonstrate that scientific arguments can indeed trigger positive political action and help to reconcile biodiversity conservation and human activities (9).

ANTONI MARGALIDA, ${ }^{1 *}$ MARTINA CARRETE, ${ }^{2}$ JOSÉ A. SÁNCHEZ-ZAPATA, ${ }^{3}$ JOSÉ A. DONÁZAR ${ }^{4}$

${ }^{1}$ Division of Conservation Biology, Institute of Ecology and Evolution, University of Bern, 3012 Bern, Switzerland. ${ }^{2}$ Department of Physical, Chemical and Natural Systems, University Pablo de Olavide, 41013 Sevilla, Spain. ${ }^{3}$ Department of Applied Biology, University Miguel Hernández, 33012 Orihuela, Alicante, Spain. ‘ Department of Conservation Biology, Estación Biológica de Doñana, CSIC, 41092 Sevilla, Spain.

*To whom correspondence should be addressed. E-mail: antoni.margalida@iee.unibe.ch

References

1. Directive 2009/147/CE of the European Parliament and of the Council of 30 November 2009 on the conservation of wild birds (http://eur-lex.europa.eu/LexUriServ/LexUriServ.do?uri=OJ:L:2010:020:0007:0025:EN:PDF).

2. Regulation CE 1774/2002 of the European Parliament and of the Council of 3 October 2002 laying down health rules concerning animal by-products not intended for human consumption (http://eur-lex.europa.eu/LexUriServ/LexUriServ.do?uri= CONSLEG:2002R1774:20070724:EN:PDF).

3. J. A. Donázar et al., Science 326, 664 (2009).

4. A. Margalida et al., J. Appl. Ecol. 47, 931 (2010).

5. J. A. Donázar, A. Margalida, D. Campión, Eds., Vultures, Feeding Stations and Sanitary Legislation: A Conflict and Its Consequences from the Perspective of Conservation Biology [Munibe 29 (Suppl.), Sociedad de Ciencias Aranzadi, Donostia, Spain, 2009].

6. Regulation CE 1069/2009 of the European Parliament and of the Council of 21 October 2009 laying down health rules as regards animal by-products and derived products not intended for human consumption and repealing Regulation (EC) No. 1774/2002 (Animal by-products Regulation) (http://eur-lex.europa.eu/LexUriServ/LexUriServ.do? uri=OJ:L:2009:300:0001:0033:EN:PDF).

7. Regulation CE 142/2011 of 25 February 2011 implementing Regulation (EC) No. 1069/2009 of the European Parliament and of the Council laying down health rules as regards animal by-products and derived products not intended for human consumption and implementing Council Directive 97/78/EC as regards certain samples and items exempt from veterinary checks at the border under that Directive (http://eur-lex.europa.eu/LexUriServ/ LexUriServ.do?uri=OJ:L:2011:054:0001:0254:EN:PDF).

8. Royal Decree 1632/2011 of 14 November, regulating the feeding of certain wildlife species with animal by-products not intended for human consumption (www.boe.es/aeboe/consultas/bases_datos/doc. php?id=BOE-A-2011-18536)[in Spanish].

9. W. J. Sutherland et al., TREE 19, 305 (2004). 

- 